\title{
Online Education Against the Background of College Japanese Teaching Reform Research
}

\author{
Chunyao Li \\ Department of Foreign Japanese \\ Dalian Neusoft University of information \\ Dalian, China 116023
}

\begin{abstract}
With the rapid development of China's social economy, the use of the Internet has been highly popular. At present, the Internet online education based on language training has received wide attention. The university Japanese major is the on-line education correlation degree higher profession, is also raises the high talented person teaching base, should take the initiative to integrate the Internet technology into the university Japanese teaching reform and the development, further optimizes the curriculum establishment, the improvement teaching method, the consummation teaching resources, This is of great significance to the teaching efficiency and the improvement of teaching quality of the college Japanese majors.
\end{abstract}

Keywords-online education; college Japanese education; teaching reform

\section{INTRODUCTION}

Online education means "Large-scale open network course", which is the newest form of network teaching. In the background of the rapid development and popularization of Internet technology, online education, which spans time and space, uses Internet technology and information technology to carry out content dissemination and learning, so that excellent educational resources can be shared and attracted much attention.

At present, many well-known educational institutions in China, such as "New Oriental", "Shanghai School", "who learn" and so on a number of online education platform rapid development, so that online education platform has received great attention. Japanese is the basic course which is second only to English in language learning, and the traditional teaching mode cannot meet the need of teaching in internet age. How to make full use of existing teaching resources and improve classroom efficiency under the background of high-speed development of online education is of great significance to the reform and development of Japanese teaching in universities.

\section{THE AdVANTAGES AND DisAdVANTAGES OF}

TRADITIONAL EDUCATION AND ONLINE EDUCATION

"Traditional education" refers to the role of teacher-led, teaching material as media, classroom as the main teaching situation, students' passive acceptance and learning. "Online education" refers to a new type of education which can effectively carry out teaching and learning activities and seek to break the educational monopoly and integrate educational resources with the help of the Internet and information technology in the separation of teachers and students. Learners' learning State is usually dynamic, continuous and interactive.

\section{A. The Advantages of Traditional Education}

The advantage of traditional education is 1. Teaching teachers occupy the leading position and organize students study and examination, which is beneficial to teachers comprehensive and systematic knowledge teaching and management of students. 2. Teachers can put forward a targeted preview of the students and work instructions, so as to effectively grasp the students ' learning situation, and then help students in the limited teaching time to achieve the best learning effect.

\section{B. Shortage of Traditional Education}

The shortage of traditional education is 1. For classroom teaching in the form of classrooms, teachers cannot be tailored to the characteristics of each student. 2. In class, teacher-centered teaching, students' learning initiative cannot be fully mobilized. 3. Paper textbooks are the main material in the classroom, the resources are limited and not rich enough.

\section{Advantages of Online Education}

1) Education costs: An important issue that many people will consider first in their education is the cost of education and the level of tuition that determines the type of education that some people receive. Compared with the previous online training schools receiving Japanese language education, the relatively lower tuition of online education has greatly reduced the cost of education, thus more to meet the needs of the market.

2) Time liberalization: With the development of society, People's life rhythm is more and faster, personal time also presents the fragmentation characteristic, therefore also has spawned the huge fragmentation education demand. It is embodied in the fragmentation of time and space of education. At present, although mainstream education is still 
the traditional way of education in schools. But the difference with the traditional school education is that the online education emphasizes to get rid of the time and space constraints of the traditional school education, which accords with the uncertainty of the learners ' education and the degree of the knowledge demand in the Internet environment. In fact, online education is targeted not only at school students, but also in all social members. To a large extent, this solves the unfair distribution of educational resources and makes it easy for anyone to have excellent learning resources. In addition, the courses offered by online education can be a variety of practical knowledge that human beings need in social life, such as cooking, decoration, fashion, childcare and so on, which fits the content fragmentation feature of Internet model. Finally, due to the powerful search function of the network, online education can provide learners with comprehensive and accurate knowledge information service of fragmentation education.

3) Learning personalization: Online education offers the possibility of personalized learning. With the development of the Internet, people can log in online education network at any time to learn, according to their own preferences, characteristics, the actual situation to choose their own learning content and learning methods. There are no restrictions on the number of elective courses or enrollment, and even students can choose different instructors. Schools are no longer the only places to learn, they can even learn on buses, homes and trains. Learners can choose the time and place to study according to their own habits.

Online education in the world to promote the concept of lifelong learning, to promote the establishment and development of learning-oriented society. This is a knowledge explosion, a rapidly changing information society, "a person has learned, if not updated every year 7\% words, cannot adapt to social changes." We must maintain the state of continuous learning in order to face the challenge of knowledge update. Online education has broken the transient and stage of college education, so that the persistence and long-term learning concepts are deeply rooted.

\section{The Lack of Online Education}

While seeing many advantages of online education, we should also look back on the problems in teaching practice and implementation of online education courses, such as:

1) Low degree of completion of the course: In the process of learning through the online education platform, learners learn related courses entirely by self-discipline and management. This will also indirectly lead to the inability of the students to complete the whole course of study.

2) Questions cannot be answered in a timely manner: The number of participants in each online education course is relatively large, so teachers must not take into account every student, leading to the interaction between teachers and students difficult to expand. Therefore, the time and opportunity for each student to communicate with the teacher is apportioned so that the teacher cannot feedback the students ' questions as timely as the traditional teaching.

3) Teaching and learning quality: With the rapid development of online education, the quality of teaching and learning is also doubtful. Compared with the traditional university face-to-face teaching mode, the teaching quality and the students ' learning quality can not be guaranteed in the online education model, and the phenomenon of teacher burnout and students ' relaxing learning is easy to appear.

Online education and traditional university education in many ways save in the difference, also each has the characteristic. Education Cost is low, education resources Superior, personalized learning characteristics are obvious, social benefits are enormous; But interactive Lack of sex, lack of learning assessment, and inadequate curriculum certification. Traditional education tuition is expensive, the educational resources are unbalanced, and the characteristics of individualized learning are not obvious, but highly interactive, learning to evaluate diversity, social benefits Significant.

\section{THE INFLUENCE OF THE DEVELOPMENT OF ONLINE EDUCATION ON THE TRADITIONAL COLLEGE JAPANESE MAJORS}

\section{A. Impact of Teaching Resources}

The traditional Japanese teaching method is a teacheroriented, teaching materials supplemented by the classroom as the core, students in the passive acceptance of the status of knowledge. However, online education can make the dissemination of information break through the limitation of time and space through the network technology, which greatly improves the efficiency compared with the traditional teaching. This allows students to acquire more resources and information through online learning, so the place of study is no longer confined to the classroom. At the same time, college students are more likely to use online resources than previous students. Students can obtain more Japanese information, Japanese news, TV dramas and other resources through the Internet, so textbooks are no longer the only medium for Japanese majors to learn and understand Japanese.

\section{B. Impact of Teaching}

Online education provides students with new learning concepts and learning methods, and can choose their own resources and courses according to their own characteristics, which exerts a subtle influence on students ' autonomous learning. In addition, because of the freedom of online education in time and space, students do not have to adhere to the traditional classroom time and place, through the time of fragmentation and any place to learn Japanese. Online education has greatly contributed to the establishment of autonomous learning awareness among Chinese students who have been cramming for a small amount of schooling. In addition, Japanese majors can learn more about Japanese 
knowledge through online education, such as Japan's climate culture, Japan's current affairs and political news, and the development of Japan's entertainment industry. Get rid of the teaching material to learn knowledge, make the student's knowledge become broader.

\section{The Influence of Teacher's Role}

Under the influence of online education, the college Japanese classroom will also change, the teacher is no longer the leader of the classroom, but gradually transformed into the guide, organizer and promoter of the classroom, to provide students as participants with guidance in the direction of learning, no longer the controller of classroom teaching. In addition, online education has broken the limitations of traditional classroom space and time, Japanese teaching is not limited to the classroom, under the support of Internet conditions, as long as the network can be unlimited time and place to participate in online courses, which, to some extent, also played down the role of teachers in traditional universities. Students become dominant in Japanese learning and can choose their own interests and practical courses according to their own circumstances and interests. So in the teaching of Japanese, teachers should conform to the trend of online education, change from the leader to help, expand the students ' Japanese learning content on the basis of teaching materials, help students choose the high quality online education course, and improve their interest in Japanese learning, instead of the former scripted.

\section{TO DEVElop JaPANESE MajORS IN THE CONTEXT OF ONLINE EDUCATION}

The trend of the development of online education, college Japanese majors should conform to this trend of the times, actively accept online education, actively innovate and adjust, promote teaching reform.

\section{A. Improving Teaching Methods}

College teachers should actively face the impact of online education, make full use of online education platform, and take their own as learners to participate in. The online education platform shares a wide range of Japanese language courses in colleges and universities around the world, and some of the top universities are also sharing courses on the platform. Teachers can find teaching materials, learn from teaching experience, learn from teaching methods, especially advanced teaching ideas and methods through online education platform. Teachers need to learn and draw on the idea of an inclusive mentality to look at online education. In addition, teachers can be based on online education teaching ideas, the Japanese teaching content and online courses, the combination of teaching materials, supplemented by the online curriculum content expansion, so that the combination of the formation of offline and line-combined teaching system, can better adapt to the various changes brought by online education.

\section{B. Encourage Students to Adjust Their Learning Methods}

In the era of online education, the traditional Japanese teaching in colleges and universities cannot meet the practical needs, the traditional teaching methods are mainly through teaching materials, offline classroom and recitationoriented education. But online education provides students with a wealth of resources and a wide range of space, so that students have the opportunity to choose their own course content or even choose their own teachers. By accepting different channels of Japanese knowledge, the independence and autonomy of Japanese learning will be greatly improved. Therefore, students should adapt to the changes of the Times, actively use online education platform resources to learn Japanese, draw away the limitations of teaching materials, through the online platform to find Japanese learning resources. Students with ability can even use the platform to communicate with Japanese learners all over the world to make up for the lack of domestic language environment. In addition, students can communicate with college Japanese teachers, students can also take the initiative to communicate and communicate with the teachers of online courses, when there is doubt in the study, should actively ask the teacher to ask questions, so that can be more effective solution to the students of Japanese learning is also very useful.

\section{Schools to Promote the "Internet +" Teaching Philosophy}

"Internet + " realizes the real-time sharing of information and breaks the gap of unbalanced educational resources, and teachers and students in some Midwestern regions can receive the newest and most advanced teaching resources through the Internet platform. Therefore, colleges and universities should actively promote the "Internet + " teaching concept of propaganda, encourage the "Internet + " technology expansion and application, at the same time in the funds appropriate to the "Internet + " equipment acquisition and software development and other tilt, effectively support the "Internet + " teaching development. For example, a university in Shaanxi province to develop the campus English Network Learning Hall, each student and English teacher has an account as the network platform "identity card", all browsing records, collection files and even "wrong title" can be found on the network platform, the network Learning Hall also has the role of communication and communication, A class of students automatically become a group, the resources within the group can be shared, but also to the teachers to ask questions. There are also colleges and universities for English teachers to open a micro-blog account, specifically used to push English learning materials and teacher-student exchanges, fully apply the online teaching resources and network platform advantages. However, in the process of advancing the "Internet $+"$, the school should insist on the teaching guideline of "both hands must be grasped and both hands must be hard" in the course of teaching on line and under the line. 


\section{Optimizing the Knowledge Structure}

In the traditional form of college English teaching, teachers usually only explain and analyze the language points and sentences as well as the background knowledge of their teaching materials, and this kind of cognitive education method is now lagging behind, unable to meet the requirements of the syllabus and social needs. But Mu class and other excellent network course resources just make up for this shortcoming, to the university English teacher provides the advantageous resources, broadens the horizon and the knowledge, may optimize own knowledge structure, but also can enrich teacher's education thought, enhances its teaching level.

\section{E. Change the Teaching Mode}

The goal of future university teaching reform is to take students as the center and to cultivate students ' individualized learning. Unlike other traditional classes, Mooc class take "Flip Class" mode, students themselves according to the future career planning and other characteristics, as well as individual capacity, according to different time, place, to choose the content of their own learning, independent learning, and can be flexible to master the progress of learning, real-time adjustment, In this way, students have a relatively wide choice of autonomy in curriculum learning, and realize the true "student-centered". In this kind of environment, the teacher is only the student's assistant, is no longer the traditional classroom instruction leader, takes the guidance and the question and answer question as the teaching method, and strives for the realization teaching goal.

\section{CONCLUSION}

Online education is showing an irresistible trend of development, breaking through the limitations of time and space, and sharing current affairs resources. Online education is quietly changing the teaching methods and ideas of college Japanese majors. In order to adapt to the influence and change of online education, reform becomes the inevitable choice for the future of college Japanese majors. Including college teachers actively promote the combination of traditional and online education model, students actively adjust their learning methods and use online platform to learn the concept of autonomy. In addition, in the promotion of online education reform, we must also pay attention to the consolidation of offline classroom teaching, because no matter how the development of online education, the university's offline education is still indispensable. Therefore, we should make use of the model of the combination of the traditional offline teaching and online education, and better train the modernized Japanese talents with the times and the perfect professional skills.

We believe that the combination of online classroom and traditional classroom "mixed learning" model will become mainstream in the future, online education and university traditional education will be mutually promoted and common development. Providing high quality learning resources for traditional universities with the help of network source, to meet more people's learning needs, and traditional universities also make full use of online education to improve the quality and efficiency of higher education, let biography University education plays a greater value in the Internet age.

\section{REFERENCES}

[1] Yang Song. The construction of "comprehensive English" MU Course + micro-course mixed teaching mode $[\mathrm{J}]$. Journal of Tonghua Normal University, 2017 (2) .

[2] Chen TingTing. Research on college English Teaching reform and development under the background of "Internet + " era $[\mathrm{J}]$ Northern literature, 2017 (5).

[3] Wang HuaMei, LiuXin. On the development of college English Teachers under the environment of MU curriculum $[\mathrm{J}]$. China training, 2017 (6).

[4] Zeng ShiQi. On the opportunity and challenge of college English teaching in the period of $\mathrm{Mu}$ class $[\mathrm{J}]$. Modern communication, 2017 (9).

[5] Yang Liu. A comparative study of MOOC online education and college traditional education [ $\mathrm{J}]$. Journal of Henan Commercial College, 2015 (2). 